\title{
A TITOKZATOS PERU - EGY MAGYAR IDEGENVEZETŐ AZ INKÁK NYOMÁBAN
}

\author{
DR. KeSZThelyi CsABA, mestertanár \\ EDUTUS Egyetem \\ keszthelyi.csaba@edutus.hu
}

Mysterious Peru - a Hungarian Guide in the Footsteps of the Incas

\begin{abstract}
ABSZTRAKT
Peru számos utazni szerető ember dédelgetett álma. Az ország bővelkedik természeti szépségekben és gazdag történelmi múltjával páratlan régészeti örökségével egyedül Mexikó vetélkedhet az egész amerikai kontinensen. Az idelátogató turisták leginkább a számos tekintetben egyedülálló inka civilizáció emlékeit és kultikus helyeit keresik: Cusco-t, a birodalom egykori fővárosát, a titokzatos Machu Picchu romvárosát, valamint a Nap, a Hold és az első inka születésének helyszínét, a Titicaca tó szigeteit. A tanulmány igyekszik rámutatni ennek a fejlett civilizációnak a sajátosságaira, egyediségére, tisztázva számos ezzel kapcsolatos tévhitet. Bemutatja azt a magas kultúrát, amely 40000 km-nyi úthálózattal, fejlett építészettel, hatékonyan müködő hírszolgálattal, igen magas szintű matematikai, csillagászati és anatómiai ismeretekkel rendelkezett. Nem ismerte viszont a magántulajdont, a pénzt, a piacot, az írást és a kereket sem. Nélkülözte tehát mindazt, amely tényezők nélkül a világ semelyik más pontján nem tudott létrejönni működőképes állam, és pláne nem egy közel 300 évig fennálló hatalmas birodalom.
\end{abstract}

\begin{abstract}
Peru is a cherished dream of many people who love to travel. The country is rich in natural beauties and with its rich historical past and unparalleled archaeological heritage, only Mexico can compete across the American continent. Tourists visiting here are mostly looking for memories and cult sites of the Inca civilization, which is unique in many respects: Cusco, the former capital of the empire, the mysterious ruined city of Machu Picchu, and the birthplace of the Sun, Moon and the first Inca, the islands of Lake Titicaca. The study seeks to point out the peculiarities and uniqueness of this advanced civilization, clarifying many misconceptions about it. The study presents the high culture with a road network of 40,000 km, with advanced architecture, efficient news service, a very high level of mathematical, astronomical, and anatomical knowledge. Which culture, however, did not know the private property, money, the market, writing, or the wheel either. So lacked, therefore, all the factors without which no functioning state could be established anywhere else in the world, and not a huge empire that had existed for nearly 300 years.
\end{abstract}




\section{Bevezetés: Miért éppen Peru?}

Nagyon sok utazni szerető ember nagy álma, hogy életében legalább egyszer eljusson az inkák földjére, és a helyszínen láthassa a festői romvárost: Machu Picchu-t, Cusco-t, a birodalom egykori fővárosát, a Titicaca tavat az uro indiánok úszószigeteivel, a titokzatos Nascavonalakat, vagy éppen Limát, a nyüzsgő, egyszerre modern és ugyanakkor patinás építészeti örökséggel bíró, számos kincset rejtő fővárost, hogy csak a legfontosabbakat említsem.

Valóban elmondhatjuk, hogy amit Európában Itália jelent a természeti és építészeti örökségek gazdagsága, müvészeti kincsek, történelmi emlékek sokasága tekintetében, az Dél-Amerika számára Peru. Nagyon sok turistát azonban visszatartanak az utazástól a viszonylag magas költségek, a hosszú és drága repülőút (Budapestről Limába a „tiszta” repülési idő minimum 16 óra), valamint az egészségügyi kockázatok. Ezek egyike, hogy az országban az ivóvizet legfeljebb mosakodásra lehet használni, de már fogmosáshoz is palackozott ásványvizet adnak. Ez nyilvánvalóan azt jelenti, hogy tilos a vízzel mosott friss zöldség és gyümölcs fogyasztása, valamint a jégkockák az italokban. A legnagyobb kockázatot azonban a 3000 méteres magasság feletti ritka levegő jelenti. Márpedig az ország területének egy jelentős része 3000 - 5000 méter közötti tengerszint feletti magasságban található. (Cusco: 3450 m, Titicaca tó: 3900 m, Puno: $3950 \mathrm{~m}$, stb. $)^{2}$ Az altiplano, vagyis az andesi felföld (4000 - $5000 \mathrm{~m}$ ) indiánjainak a szervezete jól alkalmazkodott ehhez, nekik ugyanis 2 literrel több vérük és 2000-rel több vörösvérsejtjük van, mint a síkvidéki embernek ${ }^{3}$. Mindenki mást viszont a 3000 méter fölötti tartózkodás esetén a hegyi betegség veszélye fenyegeti, lettlégyen bármilyen fiatal és kisportolt személyről is szó. Szerencsére ma már vannak ennek megelőzésére hatékony gyógyszerek (pl.: Humazolamid, Surochil, stb.)

Nekem, mint magyar csoportot vezető idegenvezetőnek, többször is volt alkalmam Peruban járni, és a helyszínen megcsodálni pompás látnivalóit. Mégsem ezért választottam előadásom témájául ezt az országot, hanem azért, mert itt találkozhatunk egy olyan középkori magas kultúrával, egy jól müködő, birodalomépítő állammal, amelynek puszta léte is ellentmond mindannak, amit mi a társadalomtudományokban, a közgazdaságtanban tanultunk, tanítunk. Az író, Tersánszky Józsi Jenő szavaival élve, aki állítólag azt mondta a zsiráfra az állatkertben, hogy: „Ez egy olyan állat, ami nincs.” Ezért erre próbálok fókuszálni és számos, egyébként

\footnotetext{
${ }^{2}$ José Miguel Helfer Arguedas: Á la découverte du Peru, Lima, 2003, 3-4. o.

${ }^{3}$ uo
} 
rendkívül izgalmas témára, mint például a preinka kultúrákra, a Nasca-vonalak kérdésére, vagy a koloniális illetve a modern Peru, legfeljebb az említés szintjén térek ki.

\section{Az országról általában}

A Perunak elnevezett földdarab 1532 áprilisában került fel az akkor már Európában Amerikának nevezett Újvilág térképére, amikor Francisco Pizarro 180 katonával és 38 lóval Tumbesnél először lépett az inkák földjére. A spanyol hódítók egy biru nevű törzs indiánjaival találkoztak először és tévesen azt hitték, hogy az ország neve Biru - Peru, ahogyan az ottaniak magukat nevezték. ${ }^{4}$ Peru DélAmerika harmadik legnagyobb kiterjedésű országa, amely a szubkontinens nyugati oldalán a CsendesÓceán partjai és az Andok mentén fekszik, 1.285.216 $\mathrm{km}^{2}$-nyi területen. Öt állammal: Ecuadorral, Kolumbiával,

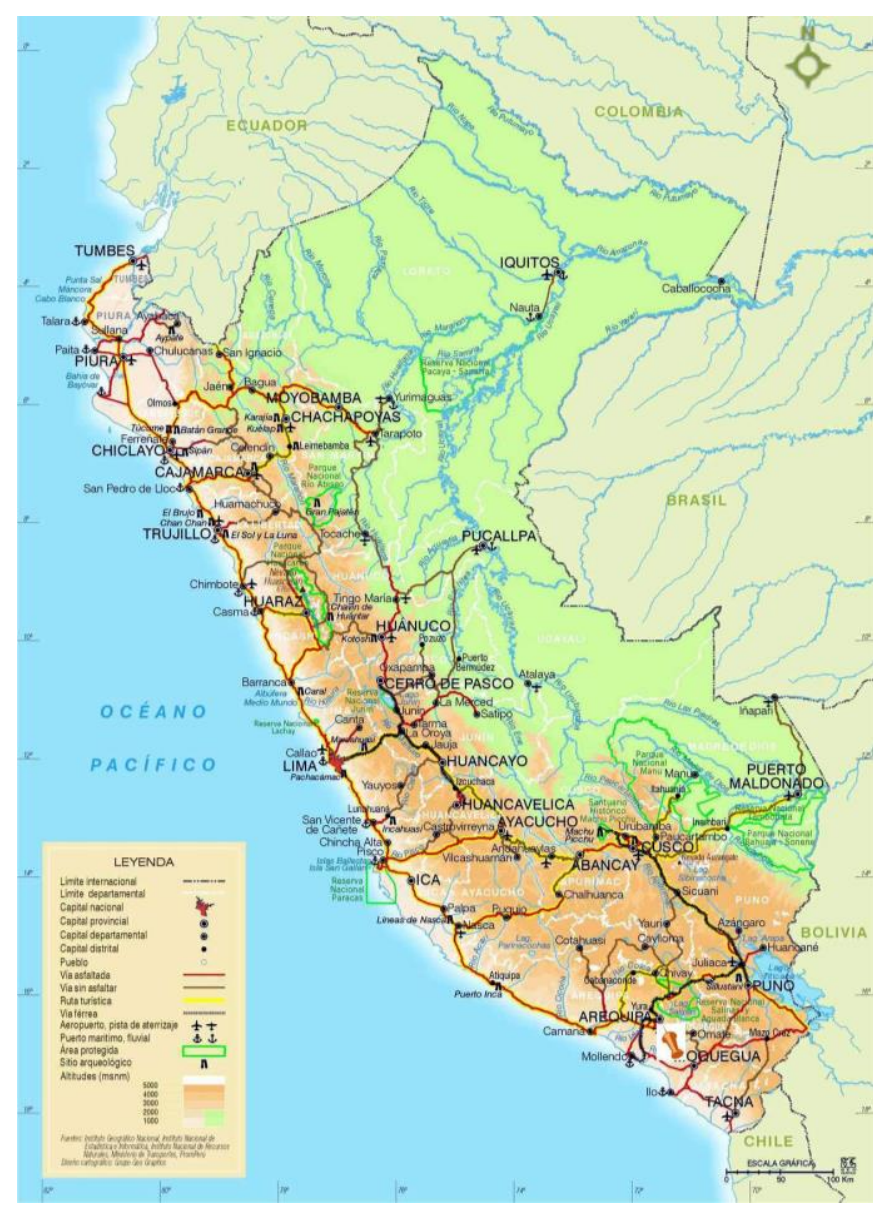
Brazíliával, Bolíviával és Chilével határos. Az ország területének 30,5\%-át adja a Sierrá-nak nevezett Andok hegység és az ún. altiplano (felföld). Legmagasabb csúcsa a Huascaran (6746 m), ezen kívül még 39 darab 5000 méter fölötti csúcsot találhatunk a perui Andokban. Az ország területének nagy részét, 58,8 \%-át a „Selvá”-nak nevezett esőerdők borítják. A „Costa”, a perui tengerpart, az ország területének 10,6 \%-át adja, amely valójában egy 3080 km hosszú, 5-170 km széles sivatagos sáv. ${ }^{5}$ Az ország lakossága 32.500 .000 fő, ennek 45 \%-a a tisztavérü, őslakos indián, 37 \%-a mesztic, vagyis $82 \%$-uk mondhatja el magáról, hogy az inkák népének leszármazottja. Jól tükrözi ezt az is, hogy három hivatalos nyelve is van az országnak: a spanyol, a kecsua és az ajmara (ez utóbbi 1980 óta). ${ }^{6}$ Az ország fővárosa, a Pizarro által 1535. január 6án alapított, a Rimac folyó partján fekvő Lima, melynek mára 10 millió lakosa van. Az ország

\footnotetext{
${ }^{4}$ Gyarmati János: Peru és a bolíviai határvidék, Budapest, 2003, 42. o.

${ }^{5}$ hu.wikipedia.org//wiki/Peru, 2021. január 27.

${ }^{6}$ Gyarmati István id. m. 60-61. o.
} 
államformája prezidenciális köztársaság. A végrehajtó hatalom feje a közvetlen választással öt évre választott elnök. ${ }^{7}$

Peru Dél-Amerika közepesen fejlett gazdaságú országának számít a maga egy főre eső 7000 USD/fő GDP-jével. ${ }^{8}$

\section{Lima, a fôváros, a perui utazások kiindulópontja}

Az inkák nyomai után eredő európai utazó igen nagy valószínűséggel programját Limában kezdi, jól lehet, a perui főváros az ország számos városával ellentétben nem prekolumbián eredetü, azt a spanyol gyarmatosítók alapították. ${ }^{9}$ Lima így is számos érdekes látnivalóval szolgál, a világörökség részét képező történelmi városközpontjával, patinás koloniális építészeti örökségével, pazar múzeumaival, hosszan elnyúló tengerpartjával. Ráadásul az is a limai kezdés mellett szól, hogy a város a tenger szintjén fekszik, és célszerü az akklimatizálódást itt kezdeni, mielött elindulnánk a magasan fekvő területekre, városokba. Utazásunkat legjobb a január és április közötti időszakra tervezni, mert áprilistól decemberig a város fölött sürü ködpaplan van, amelyből gyakran szitál az eső. Ez az ú.n. „garua”, melynek kiváltója a perui partok mentén haladó hideg Humboldt-áramlás.

A turisták általában a városközponttól kb. 8 km-re fekvő óceánparti Miraflores negyed modern szállodáiban foglalnak szállást. A hatalmas kiterjedésű városnak történelmi magja viszonylag kis területre koncentrálódik, és így gyalog is könnyüszerrel bejárható. Két nagy tér határolja: a Plaza San Martin és a Plaza de Armas vagy más néven Plaza Mayor, amely Lima igazi főtere. A két teret a híres, nevezetes sétálóutca a „Jirón de la Unión” köti össze. A Plaza San Martin közepén áll a hős argentin tábornok szobra, aki kivívta 1821-ben Peru függetlenségét. (Mariano Benliure szobra, 1921). A térről a sétálóutcán jutunk a város főterére, a Plaza de Armasra, mely az alapítás helyszíne volt, s így ez Lima legősibb része. A tér mögött folyik a város névadó folyója, a Rimac. Pompás koloniális barokk épületek szegélyezik a főteret. Sajnos az országot sújtó számos földrengés (melyek közül a legerősebb 1970-ben a Richter-skála szerinti 7,7 erősségü volt) ezt a teret is gyakran elpusztította, így az épületeket többször is át kellett építeni. Az elnöki palota (Palacio de Gobierno) jelenlegi neobarokk épülete 1938-ban épült azon a helyen, ahol egykoron Pizarro kormányzói palotája, majd később a perui alkirályok rezidenciája

\footnotetext{
${ }^{7}$ José Miguel Helfer Arguedas id .m. 6. o.

${ }^{8}$ https://data.worldbank.org. 2021. január 27.

${ }_{9}^{9}$ Pizarro nem akart beköltözni az ország belsejében 3450 méter magasan fekvő Cuscoba, nagyobb biztonságban érezte magát a tengerparton, és így egy új fővárost alapított. A sors fintora, hogy spanyol ellenlábasai 1541-ben itt gyilkolták meg.
} 
állt. ${ }^{10}$ A katedrális mai alakját 1758-ban nyerte el, benne van a hódító Francisco Pizarro díszes barokk síremléke. Itt található a Városháza és a Főposta fém-üveg szerkezetü épülete is, mely az Eiffel-féle irodaház mủve, és ma tulajdonképpen egy bevásárlópasszázs.

Lima kihagyhatatlan látnivalója a Latin-Amerikának a - mexikóvárosi Antropológiai Múzeum mellett- a legértékesebb, leggazdagabb gyüjteménye az Arany Múzeum (Museo de Oro del Peru). Az egész amerikai kontinensen ebben a két múzeumban találhatjuk a prekolumbián indián kultúrák tárgyi emlékeinek legnagyobb tárházát. Limából két és félórás repülőúttal juthatunk el az inkák ősi fővárosába, Cuscoba.

\section{Az Inkák birodalma (kb. 1300-1535)}

Mielőtt Cusco-ról (kecsuául Qosq’o, annyi, mint a világ köldöke, azaz központja) szólnék, néhány fontos dolgot kell tisztáznunk az inkák birodalmáról, melyről szinte mindenki hallott, de csak kevesen rendelkeznek pontos ismeretekkel róla. Rengeteg félreértés és tévhit terjedt el világszerte erről az egykor hatalmas andesi birodalomról és annak népéről. Az első, ami rögtön tisztázásra szorul az az, hogy nem beszélhetünk sem inka birodalomról, még kevésbé inka népről. A birodalomban ugyanis csak egyetlen inka volt, a mindenkori uralkodónak volt

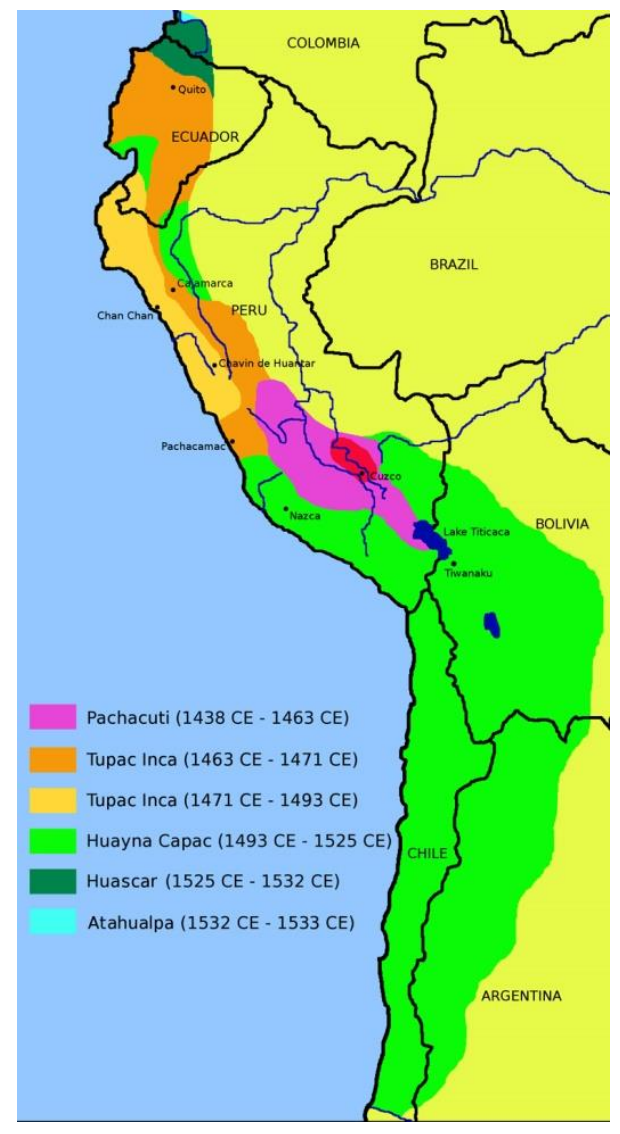

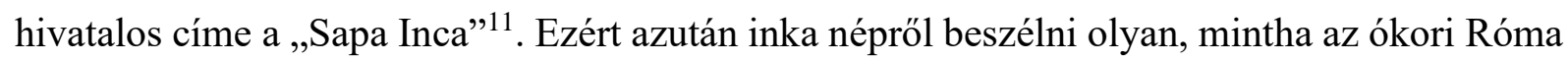
lakóit cézároknak neveznénk.

A birodalom neve kecsua nyelven" Tawantinsuyu", amelynek jelentése: négy negyed együtt. Ezzel a névvel országuk tökéletességére utaltak. Legnagyobb kiterjedését közvetlenül a spanyol konkvisztádorok érkezése előtt, 1527-ben érte el. Ekkor területe meghaladta a $2.000 .000 \mathrm{~km}^{2}$ t, és lakossága elérte a 10.000.000 föt. ${ }^{12}$ Az egykori birodalom területén ma hat állam osztozik, a mai Peru, Bolívia, Ecuador és Chile területének több, mint a fele, Argentínának egy kisebb nyugati sávja, Kolumbiának pedig egy apró dél-nyugati csücske tartozott az inkák birodalmához.) Lakosságának mintegy $70 \%$-a kecsua, $30 \%$-a pedig ajmara anyanyelvü volt.

\footnotetext{
${ }^{10}$ Az elnöki palota látogatható helyi idegenvezetővel hétfőtől péntekig 10-12.30-ig. L.: José Miguel Helfer Arguedas id.m. 13. o.

11 jelentése kecsuául: ,a leghatalmasabb úr”

12 José Miguel Helfer Arguedas id.m. 48-49. o.
} 
A birodalom hivatalos nyelve a kecsua volt, amelyet akkoriban Dél-Amerikában a birodalom határain túl is szinte mindenki beszélt, ez volt itt ugyanis a „lingua franca”, a kommunikáció legáltalánosabb nyelve, hasonlóan ahhoz, ahogyan akkoriban Európában a latin és az ófrancia, vagy manapság az angol. ${ }^{13}$

A főváros Cusco volt (1438-1533 között), itt székelt az uralkodó, a Sapa Inca, akinek hatalmi szimbóluma a „llauta” (ejtsd: jauta), a fej köré csavart, többszínű szalag volt, amelynek a közepén elől volt az ú.n. „,borla”, a homlokbojt. Az inkát mindig feje fölött a nappal ábrázolták, mivel őt a Nap gyermekének tekintették. Mítoszuk szerint ugyanis az első inka Manco Capac és nővére Mama Ocllo, a Nap gyermekeiként születtek valamikor az 1200-as évek végén. A Nap megparancsolta fiának, hogy vegye feleségül a húgát, és ettől kezdve az inkák főfelesége mindig saját lánytestvérük lett, és csak tőle származhattak törvényes utódok. Ez nyilvánvalóan vérvonaluk jelentős romlásával és egy idő után szellemi képességeik vészes hanyatlásával járt.

Az Inkák birodalma igen fejlett civilizációt képviselt, és egy müködőképes államot hozott létre, bizonyíthatóan Pachacutec Inca Yupancui (1438-1471) uralkodásától egészen a spanyol hódításig (1532), vagyis közel egy évszázadon át. Ez a civilizáció, társadalom és gazdaság azonban nagyban különbözött azoktól, amelyeket ismerünk, beleértve az aztékokat és a majákat is. Megállapíthatjuk, hogy az inkák állama, társadalma, gazdasága számos egyedi vonást tartalmazott. Megpróbálom ezeket a specifikumokat az alábbiakban pontokba foglalni.

- Nem ismerték a magántulajdont. A termőföldnek három tulajdonformája létezett, úgy mint állami, az állami kultuszt szolgáló, illetve közösségi földek. A közösségi földet közösen művelték és a termésből kötelezően adóztak az államnak, majd a maradékot egyenlően szétosztották. Az állami földeken és az állami kultusz földjein rotációs rendszerben dolgozott a falu népének egy része, másik részük pedig bevonult katonának, vagy a nagy építkezéseken dolgozott, mindig más és más. Az állam az őt megillető terményt hatalmas, földbe vájt raktárakban tárolta (nem ritkán 4000 méteres magasságban) és ezek pontos hollétéről csak az inka tudott, akinek ezen alapult leginkább a hatalma. Ez volt az ő „,aranya”, amit a spanyolok annyira kerestek. Ha azután rossz volt a termés és éhínség sújtotta volna a népet, az inkák megnyitották ezeket a raktárakat és ellátták a lakosságot.

- Nem volt pénz, kereskedelem, piac.

- Nem volt állandó, hivatásos hadsereg. 
- Nem ismerték az írást. Írást helyettesítő eszközük volt a „quipu”, amely színes zsinórokra kötött, különböző színü és méretü csomókat jelent. Ezekből számtalan fennmaradt és megtekinthetőek a múzeumokban. Jelenlegi ismereteink szerint azonban a „quipu”-val csak számokat, a könyvelést lehetett megjeleníteni. Egyes feltételezések szerint ezek esetleg történetek, események elbeszélésére is alkalmasak lehettek. Mostanáig azonban ezt senki és semmi nem tudta bizonyítani. Ezért van az, hogy a történelmük is szájhagyomány útján terjedt és viszonylag nem nagy időtávlatban is (200-250 év) már meseszerü mítoszok formájában ismerték és így adták tovább a spanyol krónikásoknak. (Pl.: az első inka születése.)

- Nagyon kevés fémet ismertek (a vasat például nem), és csak kő és bronz szerszámaik voltak. Az aranynak és az ezüstnek különösebb értéket nem tulajdonítottak, ami a pénz és kereskedelem híján egyáltalán nem meglepő. Ezeknek a fémeknek a vallási kultuszban volt szerepük, a Nap templomát mindig arannyal, a Holdét pedig ezüsttel díszítették, illetve bizonyos kultikus tárgyakat készítettek belőlük.

- Nem ismerték a kereket sem, nem voltak igavonó állataik, így szárazföldön csak gyalogosan, az elökelők pedig gyaloghintón közlekedtek. Nyilvánvalóan ez a szállítást is igencsak megnehezítette.

Ezzel szemben a birodalomnak nagyon fejlett, teraszos müvelésü mezőgazdasága volt, amelyhez kiterjedt öntözőcsatorna-hálózatot építettek. Legfőbb terményük a kukorica volt, amelyből még sört is készítettek. A munka mindig ünnepi keretek közt zajlott, zenével, tánccal, evéssel és ivással. A mezőgazdasági munkák új ciklusát maga az inka nyitotta meg személyesen a június 24-ei napfordulón (Inti Raymi) és a munkából az előkelők is kivették a részüket. Ez volt a legnagyobb ünnepük. Az Inti Raymi hagyománya ma is él, és a kecsuák és ajmarák legfontosabb ünnepének számít napjainkban is, bárhol éljenek is a világban. (Magam is tanúja voltam egyszer Rómában az ott élő peruiak, bolíviaiak, ecuadoriak, chileiek ünneplésének.)

Nagyon fejlett volt az építészetük is. Az inka kultúra legjellemzőbb, birodalomszerte leginkább szembeötlő vonása a kőépítészet, és az a képesség, hogy épületeiket a tájba illesszék. Ezen felül épületeik rendkívül stabilak is voltak. Az egymáshoz illesztett, csiszolt, kváderkövek közé még egy késpengét sem lehetne becsúsztatni. Ezért van az, hogy a spanyol hódítók saját épületeiket mindig az inkák által épített épületek alapjaira emelték, megőrizve azoknak eredeti szerkezetét. Ezek az építmények ugyanis földrengésállónak bizonyultak, míg a hódítók által saját módszereik szerint épített egyéb épületek kártyavárként omlottak össze a gyakori földrengések 
alkalmával. Az általában dísztelen, monoton épületeik szépségét a festői tájba illesztésük biztosította. Ritka kivételként egy-egy épületet díszíthetett a falára festett kígyó, puma vagy kondorkeselyü. Legtöbbször építőanyagként a kváderkövet használták, de építkeztek, elsősorban a tengerparton, adobetéglából is. Az építkezéseken is a faluközösségek dolgoztak, akik munkájukért fizetségként ételt és italt kaptak. ${ }^{14}$

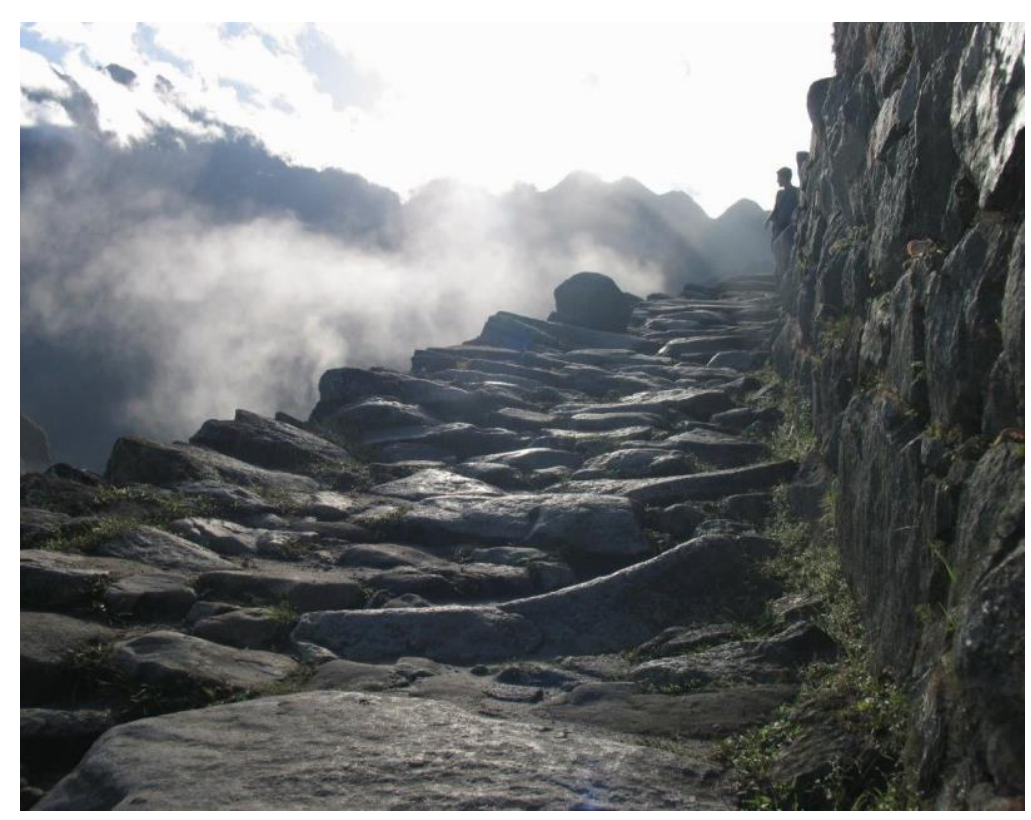

Az inka civilizáció egyik legjelentősebb és legismertebb teljesítménye a birodalom úthálózata, melyet méltán tekinthetünk az Újvilág legnagyobb ősi építményének. A birodalom kb. $40.000 \mathrm{~km}$ hosszúságú, a kolumbiaiecuadori határtól Santiago de Chiléig kiépített úthálózattal rendelkezett. Ebből mára nagyjából $23.000 \quad \mathrm{~km}-\mathrm{t}$

térképeztek fel, ami ismert és ma is járható. (Számos utazási iroda szervez túrákat az ú.n. inka ösvényen.) Szélességük 2-15 méter között változott, az adott talajviszonyoktól függően. Mocsaras területeken töltésutakat építettek, kisebb folyókon kőpilléreken támaszkodó fahidakkal, nagyobbakon pedig növényi rostokból készítette függőhidakon vezették át az utakat. Az úthálózat kiemelkedő szerepet játszott a hírközlésben és a szállításban. Az utak mentén nagyjából egynapi járásnyira pihenőhelyeket, állomásokat létesítettek, ezeket „tampu”nak nevezték. (A mai kecsua nyelven ezt „tambo”-nak mondják. Egykori helyeikre utal számos perui helységnév pl.: Ollantaytambo, Limatambo, stb.) Ezeken a helyeken kaptak szállást és élelmet az utazók, és itt váltották egymást a futárok, akiknek a neve „chaski” volt. A futárszolgálat igen fejlett volt, a nagyobb utak mentén igen sürün voltak váltóállomások, általában 4-5 kilométerenként és így a hírek Cusco-ból egy hét alatt eljutottak a legtávolabbi vidékekre is, pl. Quitoba, Santiagóba. Az utakon a hivatalnokok államügyekben vagy felügyelet céljából utaztak, és az uralkodó is szüntelenül úton volt, hogy biztosítsa alattvalói hűségét,

\footnotetext{
${ }^{14}$ Gyarmati János id.m. 235. o.
} 
esetleg hadjáratokat vezessen. Az utak az államhatalom szimbólumai voltak, és az államhatalom mindenkori jelenlétét bizonyították a legtávolabbi helyeken is. ${ }^{15}$

Külön tanulmány tárgyát képezhetnék a birodalom tudományos ismeretei, müvészete, mitológiája. Itt csak dióhéjban, az említés szintjén tudunk ezekkel foglalkozni. Rendkívül fejlett volt a csillagászatuk, és komoly matematikai ismeretekkel rendelkeztek. Számos emlék maradt ránk, ami erre utal. (Obszervatóriumok, az inkák kozmológiáját bemutató ábrázolás, a cusco-i Naptemplom falán, amelyen több csillagképet, köztük a Dél keresztjét is láthatjuk.)

Mitológiájuk számos istent tartalmazott, ezek közül a legfontosabbak: Viracocha, a teremtés istene, a Napisten, és felesége a Holdistennő, Pachamama (a Föld Anya), Mama Qucha (Tenger Anya), Saramama (Kukorica Anya), Kukamama (Koka Anya). Három szent állatuk volt, amelyeknek számos képi ábrázolása fennmaradt. A kuntur (a kondorkeselyü) az égi túlvilágot, a puma a földi létet, míg az amaru (a kígyó) pedig az alvilágot jelképezte. ${ }^{16}$ Ezek tisztelete egyébként valamilyen formában máig fennmaradt, a már zömükben katolikus kecsuáknál és ajmaráknál, a szinkretizmus egy sajátos formájaként. Perui körutunk során az inka civilizáció három kultikus, sőt mondhatni szakrális helyét látogatjuk meg: Cusco-t, az ősi fővárost, a titokzatos Machu Picchu-t és a Titicaca tavat, ahol a Nap gyermekeiként megszületett az első inka és húga.

\section{Az inka emlékek nyomában}

\section{Cusco}

A spanyol krónikák szerint idejött a Titicaca tótól az első inka Manco Capac és ő építtette az első házat a mai Quorikancha helyén és a Naptemplomot, valamikor a Kr. u. 1200-as években. A város máig fennmaradt szerkezetét Pachacutec inka (1438-1471) alakította ki. Ekkor épült ki a birodalmi főváros kettős főtere, a mai Plaza de Armas helyén a Haukaypata (kecsuául a Nyugalom tere), amelyet a Saphi folyó választott ketté. Ma a gyarmati korban épült házsor is kettéosztja. Ez volt a birodalom szakrális központja. Tengeri homokkal töltötték fel, melybe áldozatul arany és ezüst szobrokat rejtettek jelezve, hogy a tenger minden dolgok eredete. A tér közepén állt az emelvény, amelyen az uralkodó a szertartások során helyet foglalt. A teret az inkák palotái szegélyezték, illetve fontos szakrális, vagy egyéb középületek. Minden inka saját

\footnotetext{
${ }^{15}$ Gyarmati János id.m. 253-254. o.

${ }^{16}$ José Miguel Helfer Arguedas id.m. 38-39. o.
} 
palotát építtetett, amelyben halála után is örizték mumifikált holttestét. Ezeket a múmiákat a szertartásokkor a Nap képmásával együtt a térre hozták. A térről indult a birodalom négy főútja.

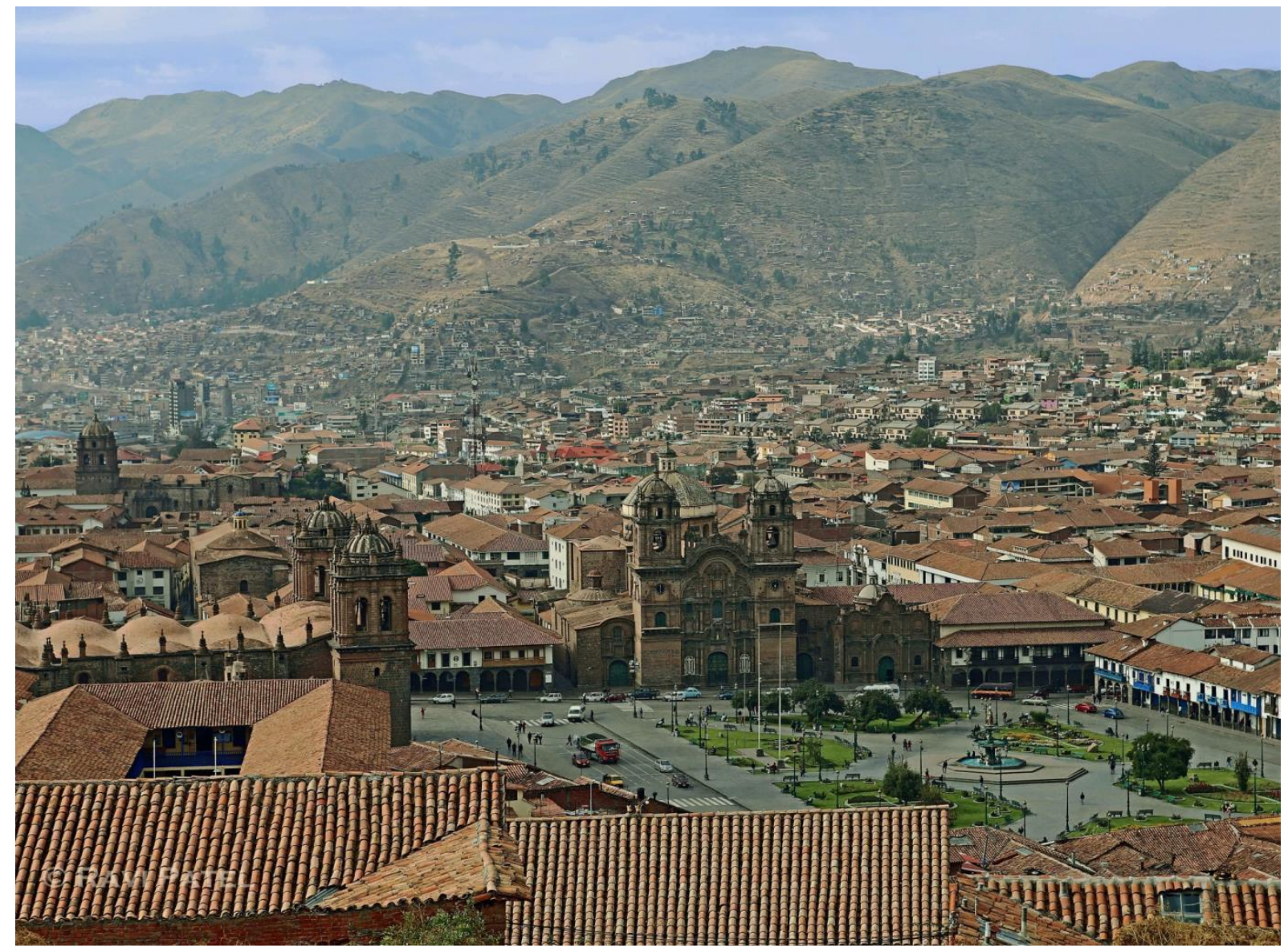

A város formáját úgy alakították ki, hogy az a szent állatuknak, a pumának a testét formázza, az állat fejét pedig a város fölött emelkedő hatalmas erődítmény, a Saqsawaman képezte. Ez a 3600 méter magasan fekvő vár védte a 3450 méteres magasságban elterülő várost az ellenséges támadásokkal szemben. A város lakossága a spanyol hódítók érkezésekor, azok beszámolója szerint, 100.000 fő volt. (A korabeli Párizsé 40.000 fő.) Cusco számtalan érdekes látnivalója közül ehelyütt emeljük ki a legfontosabbat. Ez a Quorikancha (kecsuául: Arany udvar), mely a legfőbb isteneknek egy belső udvar köré emelt épületegyüttese volt és kozmológiájuk szerint itt volt a világmindenség központja. Ez volt a birodalom legfontosabb kultuszhelye. A Naptemplom és a Holdtemplom falainak felhasználásával, egyes eredeti részek megőrzésével ide építették a spanyolok a Santo Domingo-t, vagyis a Szent Domonkos templom és kolostoregyüttest. Cusco-ból teszünk egy egész napos kirándulást a Machu Picchu-ra. 


\section{Machu Picchu (jelentése: Öreg Hegy)}

Az inkák által szentnek tekintett Urubamba folyó festői völgyében halad az ú.n. cikk-cakk vonat ${ }^{17}$ Dél-Amerika régészeti fővárosa felé. A vasútállomástól egy kb. 20 perces autóbuszos szerpentin út után érkezünk a titokzatos inka romvároshoz, amelynek létét a közel 300 éves spanyol uralom alatt mindvégig sikerült eltitkolniuk a hódítók előtt. A világ csak 1911-ben szerzett tudomást a létezéséröl.

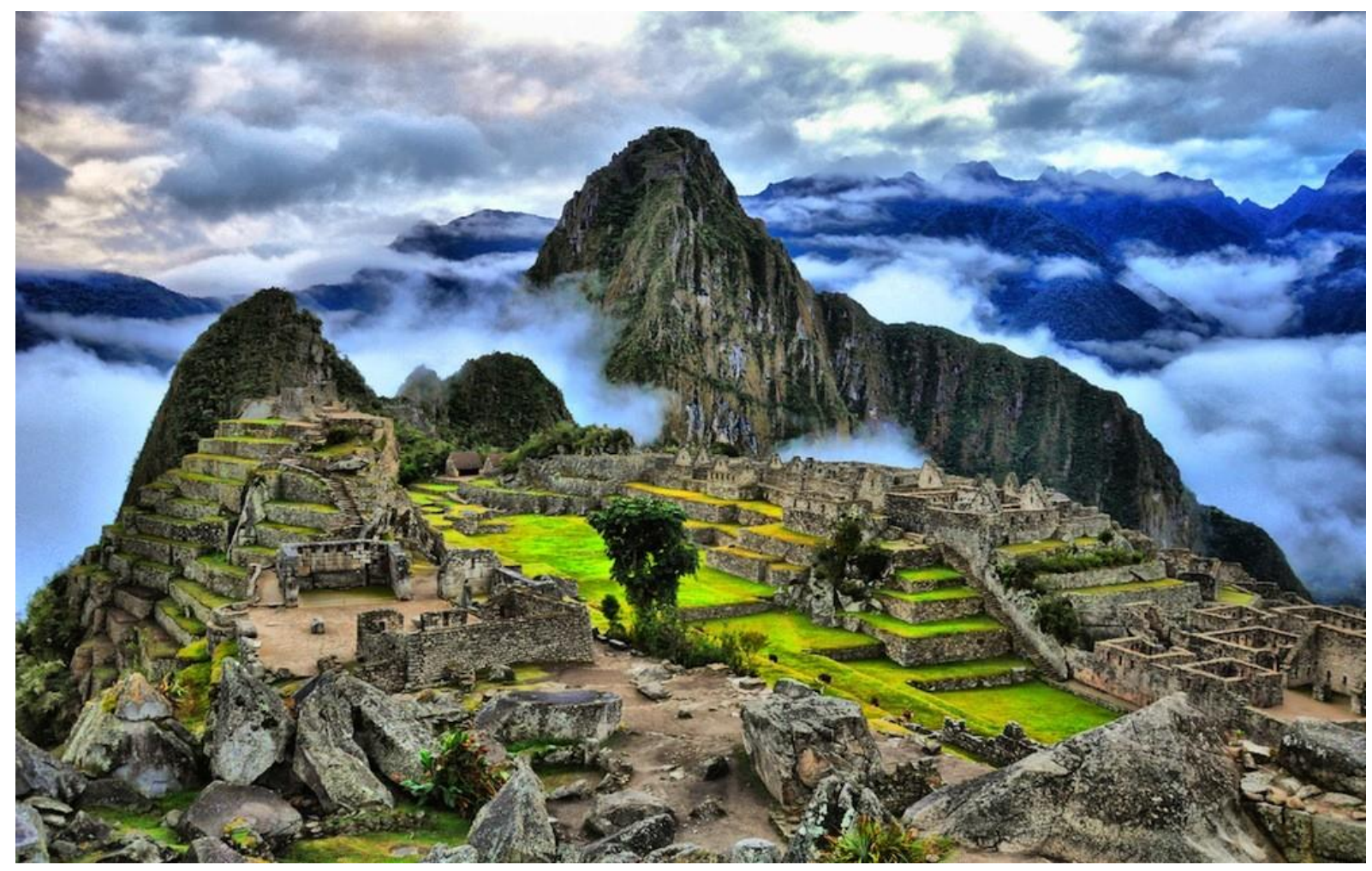

Az első európaiak, akik megpillanthatták, az angol régész és történész Hiram Bingham és fényképésze, a magyar Fejős Pál voltak. ${ }^{18}$ Azóta ez Peru legfőbb turisztikai vonzereje. 2007ben méltán választották az újkori világ hét csodája közé. kevés ehhez fogható ősi romváros létezik a világon, és ilyen festői környezetben pedig egy sem. A hajdani város egy kb. $400 \mathrm{~km}^{2}$ -es területü sziklatömbön fekszik és amelyet különösen festőivé tesz az észak-nyugati végében emelkedő Huayna Picchu (Fiatal Hegy), általában ez látható az ismert fotókon a romváros háttereként. A város eredeti nevét nem ismerjük. A Machu Picchu név Hiram Binghamtól ered, aki a kecsuáktól hallotta, hogy a magasabb csúcsot így hívják. Ő ezt a város nevének gondolta. Machu Picchu alapvetően két részre oszlott: egy mezőgazdasági és egy városi szektorra. Az előbbi kőből rakott földművelő teraszok százaiból és öntözőcsatornákból, valamint néhány

\footnotetext{
${ }^{17}$ Mivel Cusco 3450 méteres magasságban fekszik, a Machu Picchu pedig majdnem pontosan 1000 méterrel lejjebb (2450 m), ezért a vonat biztonsági okokból nem egyenes vonalban, hanem úgynevezett cikk-cakkokat leírva halad. Innen a név.

${ }^{18}$ José Miguel Helfer Arguedas id.m. 64. o.
} 
házból állt. A városi szektor három részre osztható: a dél-nyugati részen állnak a kultikus épületek, a Torreón az alatta elterülő kis barlanggal, a rituális fürdők, a szent tér a fö templomokkal és az Intiwatana, amelyet a sziklából kiálló függőleges nyúlvány miatt sokan naptárnak vagy napórának, egyesek pedig iránytünek gondolnak. A városi szektor középső részét egy több szintre tagolt, hosszan elnyúló tér foglalja el, míg északkeleti oldalán feltehetően a kiszolgáló személyzet, esetleg a „napszüzek” szállása és a mühelyek foglaltak helyet.

A legtöbb épület funkcióját sikerült meghatározni. A városi szektor bejáratánál egy ú.n. Örház állott. Számos lakóház, szakrális épület, egy csillagvizsgáló és 16 fürdőépület is volt benne. A víz forrása a Machu Picchu hegy mögött volt, és a Napkaputól vezették a vizet a városba. (Ma ez a forrás a romterület mellett található előkelő szállodát táplálja.) Ezek mind a város lakóinak fejlett civilizációját, széleskörü tudományos ismereteit bizonyítják. Paradox módon azonban mindmáig számos kérdést nem tudtak megválaszolni a város történész, régész kutatói. Nem ismert például, hogy mikor és milyen céllal alapították, hogy hívták, mettől meddig laktak benne lakói, akikről szintén alig tudunk valamit. Ezeknek a kérdéseknek a megválaszolásával még adós a tudomány, jelenleg csak feltételezések vannak. A legvalószínübbnek az látszik a leginkább elterjedt feltevés szerint, hogy a várost a XV. században Pachacutec inka uralkodása idején építették és valamikor a XVIII. század közepén néptelenedhetett el. De ezek csak feltételezések. Jellemző, hogy valahányszor ott jártam, a perui kollégák ezeket mindig máshogy magyarázták.

\section{A Titicaca tó (A Titicaca jelentése: a Párduc Könnye)}

Cusco-ból autóbusszal Peru déli részére, a bolíviai határhoz közel, 3850 méter magasan fekvő Puno városába megyünk, amely a Titicaca tó partján fekszik. A mi Balatonunknál kb. 14-szer nagyobb, $194 \mathrm{~km}$ hosszú, átlag $65 \mathrm{~km}$ széles, összesen $8300 \mathrm{~km}^{2}$ vízfelületü Titicaca tavon két ország, Peru és Bolívia osztozik (nagyjából $60 \%$-a tartozik az előbbihez, és $40 \%$-a az utóbbihoz). ${ }^{19}$

A perui partok mentén találjuk az uro (vagy uru) indiánok ú.n. úszószigeteit. Ezeket a szigeteket lakóik szárított totorából (amely frissen, zölden nagyon hasonló a mi póréhagymánkhoz és ugyanúgy fogyasztható) készítik és ugyancsak totorából fonott zsinórokkal kötözik a tó aljához, így azok a vizen lebegnek. Ma kb. 1500-2000 saját nyelvet beszélő indián él nagyjából 40 szigeten. A sziget házai szintén totorából készülnek, sőt ebből építik hajóikat is. A világhírü

\footnotetext{
${ }^{19}$ José Miguel Helfer Arguedas id. m. 40. o.
} 
norvég utazó és író, Thor Heyerdahl (1914-2002) is részben a balsafa mellett a totorából építette uro indiánok közremüködésével a Kon-Tiki nevü tutaját, amellyel 4300 tengeri mérföldet megtéve eljutott Peruból Polinéziába 1947 májusában. ${ }^{20}$ Az úszószigetek egyikén iskola is van, idejárnak a többi szigetek gyerekei is. Bár nincs vezetékes áram, mégis van napkollektorok segítségével müködtetett televíziójuk, számítógépük. Az urok szigetei kihagyhatatlan látnivalók az idelátogatók számára.

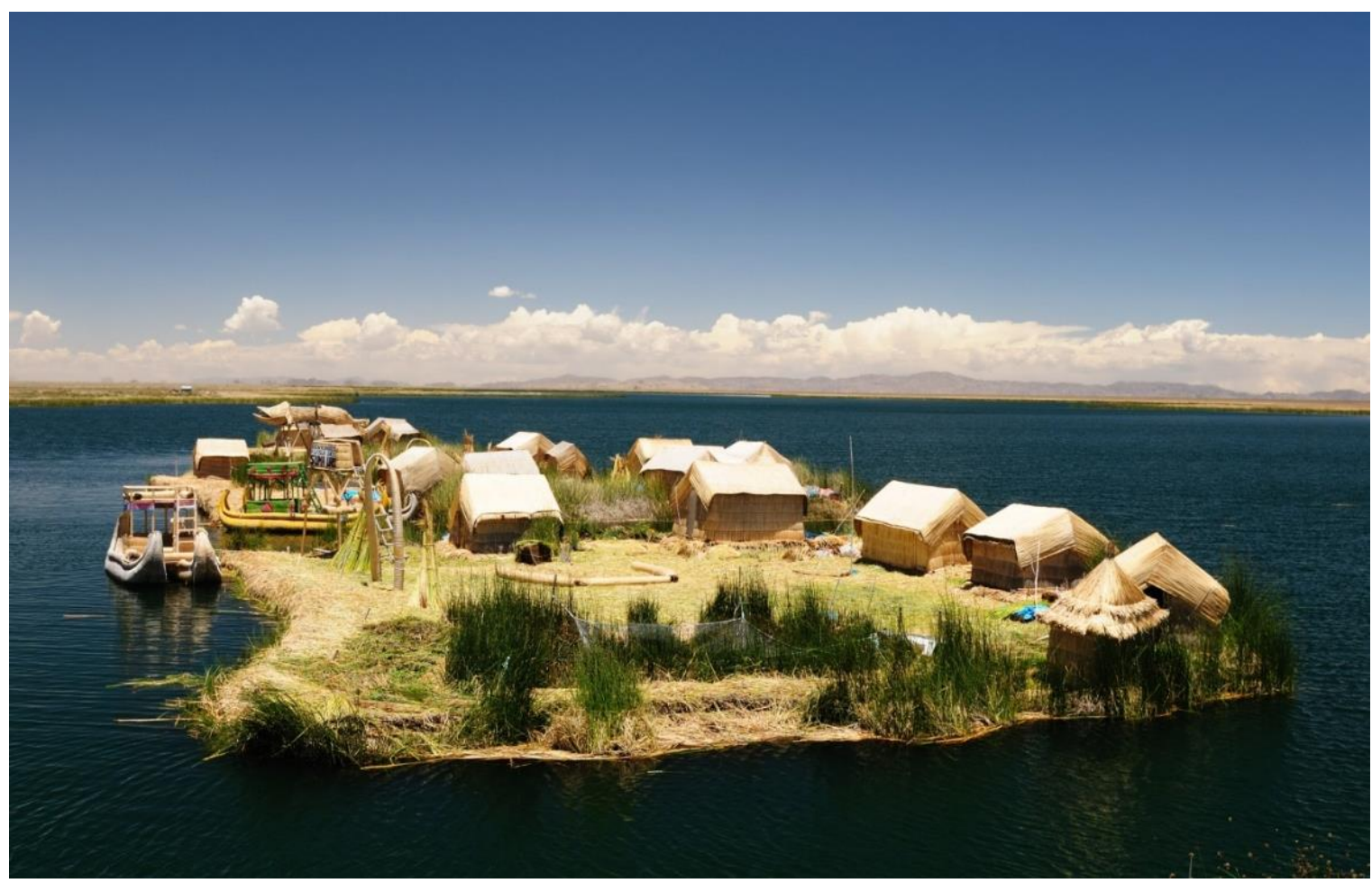

A Titicaca tó volt az inka birodalom egyik legszentebb helye. Az inkák eredetmítosza szerint ugyanis a tónak a ma Bolíviához tartozó részében található Napszigeten kelt fel először a Nap a Titikala nevü hatalmas sziklából. Viracocha, a Teremtő pedig a tó vizére helyezte az első emberpárt. $^{21}$ A Holdszigeten született a Hold. A tavat tekinthetjük az inka birodalom bölcsőjének, ugyanis itt született a Nap és a Hold gyermekeként az első inka, Manco Capac, és innen indult el Cusco felé, hogy az inkák egy kis andesi törzs fönökeiből egy hatalmas birodalom uraivá legyenek.

\footnotetext{
${ }^{20}$ Lásd: Thor Heyerdahl: Tutajjal a Csendes-Óceánon, Budapest, 1962. 5-2321. o.A szerző ezzel az úttal akarta igazolni a dél-amerikai indián lakosság polinéz eredetét.

${ }^{21}$ Gyarmati János id. m. 294. o.
} 


\section{Végső konklúziók}

Összegzésképpen elmondhatjuk, hogy Peru egy ,álomúticél”, ahol a kalandvágyó turisták, akik vállalják az utazással járó nehézségeket (nagy távolság, magaslat, stb.) páratlan élményekben részesülhetnek. Találkozhatnak csodás természeti szépségekkel, ősi romvárosokkal, számtalan pazar műemlékkel és máig megfejtetlen titkokkal (Nasca vonalak, quipuk, stb.). Láthatnak úszó szigeteken élő indiánokat, eljuthatnak számos világörökségi helyszínre és találkozhatnak egy, a maga egyediségében az emberiség történetében páratlan civilizáció emlékeivel. Mindennek fényében a gyakorlati tapasztalatom az, hogy perui utazásokra a magyar utazóközönség körében is van igény, és ha nem is nagyszámú, de igényes és fizetőképes kereslet is. Ezért a pandémia elmúltával a nagy magyar utazási irodák kínálatából továbbra sem hiányozhat az inkák titokzatos földje. 


\section{FELHASZNÁLT IRODALOM}

1. José Miguel Helfer Arguedas Á lá découverte du Pérou Ediciones del Hipocampo S.A.C. Lima, 2003

2. Gyarmati János Peru és a bolíviai határvidék Dekameron Könyvkiadó Bp, 2003

3. Cholnoky Jenő: A Föld és élete Bp., 1930

4. Thor Heyerdahl Tutajjal a Csendes-óceánon Gondolat Bp., 1962 